\title{
Low Grade Astrocytic Tumor
}

National Cancer Institute

\section{Source}

National Cancer Institute. Low Grade Astrocytic Tumor. NCI Thesaurus. Code C116342.

A grade I or grade II astrocytic tumor. This category includes pilocytic astrocytoma

(grade I), subependymal giant cell astrocytoma (grade I), and diffuse astrocytoma (grade II). 